\title{
Sedimentary System Characteristics of Deng-3 Section on Paleo-central Uplift Belt in Northern Songliao Basin
}

\author{
Siyang $\mathrm{Li}^{1, \mathrm{a}^{*}}$ \\ ${ }^{1}$ School of Earth Sciences and Resources, China University of Geosciences, Beijing, 1300083 \\ alsycugb@163.com
}

Keywords : Palaeo central uplift belt, Deng-3 formation, Sedimentary facies, Sedimentary characteristics

\begin{abstract}
On the regional sedimentary background, the sedimentary facies was studied by well-to-seismic integration, in view of the complicated situation of the researched region. Based on the analyses of lithologic association, sedimentary structure, paleontology, rock color and its contact relations, well logging curve shape, etc., sedimentary microfacies was analyzed by sand group around the whole area in detail. After sedimentary microfacies of single well and sand body connectivity of multi-well and seismic facies were analyzed, the sedimentary system was studied, in combination with regional sedimentary background, the palaeo geomorphology and thickness and lithology. The results show that, in Deng-3 section, its reservoir is mainly fluvial facies deposition, river channel sandstone is well developed, with large sandstone thickness and high sandstone percent, river channel microfacies has obvious advantages.
\end{abstract}

\section{Introduction}

Palaeo central uplift belt is located in the northern Songliao Basin on the east side of Daqing [1], and is a slope zone controlled by the deep fault developed between the ancient central uplift belt and Xujiaweizi deep fault. The palaeo central uplift region in the west is lack of the formation beneath Deng-2 section, Deng-3 section formation directly overlap it. Xujiaweizi is a completely developed fault in the east side of it.

Denglouku formation is a set of strata in the deep part of Songliao Basin, with the most widely distributed and the largest thickness, the maximum thickness is up to 1300 meters. The Denglouku formation is divided into four lithologic sections, Deng-1 section is a mottled conglomerate section, Deng-2 section is dark mudstone, Deng-3 section is the massive sandstone, Deng-4 section is transitional lithology. The massive sandstone rock types of Deng-3 section are mainly including: gray, gray green massive sandstone with gray green, brown gray, gray brown sandy mudstone, the bottom is muddy gravel, and the finer the positive rhythm generally, this section thickness is up to $650 \mathrm{~m}$. In order to efficiently explore and develop Deng-3 section, it is necessary to study the sedimentary system characteristics and predict strata thickness distribution of Deng-3 section.

\section{Sedimentary Characteristics}

The characteristics of sedimentary facies. Fluvial facies is the composite of the river sedimentary environment [2] and its sedimentary characteristics. Different types of rivers, its environment is different from the sedimentary characteristics, so its sedimentary facies is different. According to 
the environment and characteristics of sediment, fluvial facies can be further divided into four kinds of microfacies including river, crevasse-splays, natural levees and flood land (refer with: figure 1, figure 2).

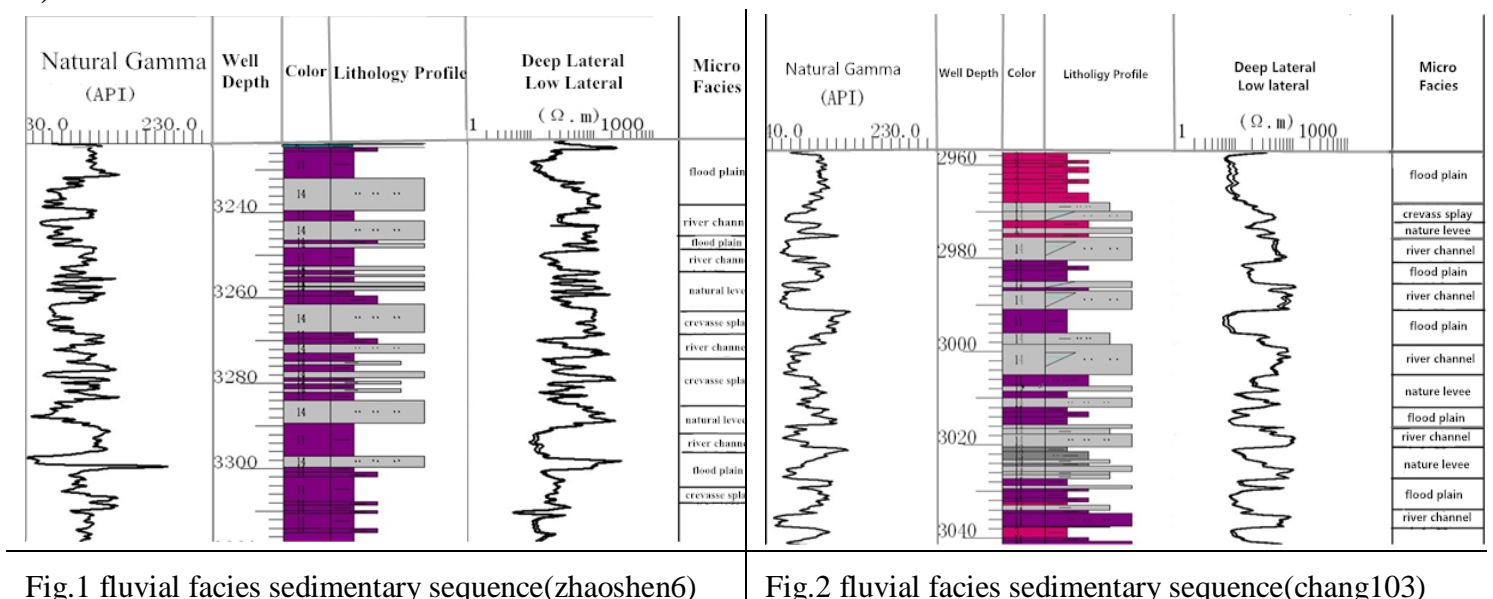

Channel microfacies. The rock types are mainly sandstone, conglomerate next, sandstone thickness is greater than $3 \mathrm{~m}$, which is the most coarse of river sedimentary phase. In the vertical, it often occurs that the size from coarse to fine or lithology positive rhythm from bottom to top. The main types of bedding are large and medium-sized groove because of the water ripple formation or tabular cross-bedding, parallel bedding occasionally. In the vertical direction, regular graded mostly due to the riverbed migration and point bar sediment lateral accretion (refer with: figure 1, figure 2).

Natural levee microfacies. The lower part of the natural levee is mainly composed of siltstone, developed small groove cross-bedding and wave cross-bedding, or climbing ripple texture and texture, its upper part is a mudstone with level texture. Lithology is characterized by interbedded sand and mud, mudstone thickness is larger, the main color is purple red, sandstone thickness is smaller, sandstone thickness is less than $1.5 \mathrm{~m}$ (refer with: Fig. 1).

Crevasse splay microfacies. During the flood flow, when the velocity was very large, the flood rushed to open the natural levee forming crevasse channel, crevasse channel through the natural levee, and finally into the adjacent flood land, due to a sudden drop in velocity, sediment began to accumulate in the vicinity of the river burst, formed the section distribution, therefore, called a crevasse splay. The granularity of lithology is some of the crude compared with nature levee deposition [3], is also characterized by sand mud interbed, sandstone thickness of $1.5 \mathrm{~m} \sim 3 \mathrm{~m}$ (refer with: Fig. 2).

Floodplain microfacies. Floodplain is located outside of the levee, low-lying and flat, poor drainage. Floodplain is the flat part of the lateral bed and the bottom of the valley, there is no water in the water level period, water overflowing the river bed in the flood period, submerging flat bottom, forming floodplain sediment.Floodplain deposit in mudstone and mudstone color is purple red [4]. Vertical also has fining upward trend, mainly are wavy bedding and inclined wavy bedding, ripple marks visible asymmetry (refer with: Fig. 1, Fig. 2).

Multi-well sedimentary microfacies analysis. On the regional sedimentary background, according to the lithologic association of individual well, sedimentary structures, palaeontology, rock color, rock contact relationship, logging curve shape, etc., the 47 wells around the whole region had been carried on the detailed analysis of sand group sedimentary microfacies. Deng-3 section or Deng- 4 section in the study area mainly develope fluvial facies. On this basis, in order to find out the spatial distribution law of the sedimentary microfacis, 10 well-tie sandstone analysis profile map was drown with selected 10 controlled frame profiles. 
From the south to the north of the profile, the wells include: Tongshen-1, Tongshen-2, Weishen-2, Wang-901, Wang-902. The sedimentary facies type of the Denglouku group in this profile are mainly fluvial facies, the lower part of Deng-2 section develops only in Well Tongshen-1 and Tongsheng-2, and is mainly delta-plain sub-phase with a small amount of distributary channel deposits developing, other wells lack of this formation. The upper stratum of Deng-2 section develops in all wells, except Well Wang-901. Delta plain subfacies develops at the lower part of Well Tongshen-1, Fluvial facies develops in other wells. Channel microfacies partially develops only in Well Tongshen-2, and doesn't exist in other wells. Fluvial facies develops at the lower part of Deng-3 section strata in all wells, while, the river channel microfacies develops best in Well Tongshen-2 and Wang-902, and large set of sandstone are their main feature; in Well Wang-901 and Well Tongshen-1, there are mainly flood plain microfacies. Fluvial facies develops at the upper stratum of Deng-3 section in all wells, while the river channel microfacies develops best in Well Tongshen-1, Well Tongshen-2 and Well Wang -902, and large set of sandstone is their main characteristics; Well Weishen-2 and Well Wang-901 are characterized by flood plain microfacies. Compared with the upper strata of Deng-3 sections, although fluvial facies develops at the lower part of Deng-4 section in all wells, sandstone does not develop and flood plain microfacies mainly develops, channel microfacies and large set sandstone develops only in Well Wang-902. Compared the upper formation with the lower part formation of Deng-4 section, sandstone is less developed, flood plain microfacies mainly develops.

Planar features of sedimentary system. On the basis of analysis on single well sedimentary microfacies, associated well sand body connectivity and seismic facies, in combination with regional sedimentary background, geomorphology, thickness and lithology, the sedimentary system were analyzed. Because the sandstone in the Deng-3 section overall develops, while the sandstone in Deng-4 section overall does not develop, different standards to Deng-3 and Deng-4 section were selected to determine dominant sedimentary microfacies in the well point. For the formation of Deng-3 section, if the ratio of channel sandstone to formation is more than $20 \%$ or the ratio is between $15 \% \sim 20 \%$ and the ratio of sandstone to formation is more than $30 \%$, the formation is determined as channel dominant microfacies. If the ratio of channel sandstone to formation is less than $15 \%$ or the ratio is between $15 \% \sim 20 \%$ and the ratio of sandstone to formation is less than $30 \%$, the formation is determined as flood land dominant microfacies. For the formation of Deng-4 section, if the ratio of channel sandstone to formation is more than $10 \%$ or this ratio is between $5 \%$ $\sim 10 \%$ and the ratio of sandstone to formation is more than $20 \%$, the formation is determined as channel dominant microfacies. If the ratio of channel sandstone to formation is less than $5 \%$ or this ratio is between $5 \% \sim 10 \%$ and the ratio of sandstone to formation is less than $20 \%$, the formation is determined flood land microfacies. The interval studied is too thick, and exploration wells distribute very unevenly, so we only compiled a planar graph of the ratio of sandstone to formation for reflecting the features of sedimentary system.

The sedimentary system planar characteristics of the lower stratum of Deng-3 section. The lower strata of Deng-3 section, except the small area near the north of well Da2 and Yongle region in the southern area are missed, distribute in all other regions. From the drilling data of 46 wells in which the lower strata of Deng-3 section is drilled, there are 34 wells develop channel sandstone, the thickness of sandstone is large, the ratio of sandstone to formation is high, channel microfacies is dominant, it reflects that, in the section formation sedimentary period, the range of water body is large, river energy is strong, sedimentary thickness is big, the time of water flooding is longer. The river channel is widely distributed and wider, the extension is longer, material source is mainly in the north. The river channel microfacies is main in most parts of the region because of river 
channel's swinging and overlaping, the area in which flood plain microfacies dominant is very small, and distributed mainly around well Da2 in the northern and Yongle area in the southern.

The sedimentary system planar characteristics of the upper stratum of Deng-3 section. Compared with the lower strata of Deng-3 section, the upper strata of Deng-3 section distributes in the whole region, From the drilling data of 46 wells in which the lower strata of Deng-3 section is drilled, there are 37 wells develop channel sandstone, the thickness of sandstone is large, the ratio of sandstone to formation is high, channel microfacies obviously is dominant, reflecting river energy stronger, which is the most developed zone of Denglouku group channel, the river occupies almost the whole region, sedimentary thickness is big [5]. Material source direction remains in northern direction. Only in the middle of the high part of the uplift zone, sandstone is relatively undeveloped and the flood land deposits of flood plain is dominant, while in most part of this region, sandstone develops well and river channel sediment is dominant.

Analysis of sedimentary evolution history. Deep Huoshiling group, Shahe group, Yingcheng group, Denglouku group of paleo central uplift belt, during the development in the process of evolution, sedimentary characteristics, both inheritance and mutations, both gradual change, also have a sudden change. In terms of the sedimentary characteristics [6], it can be divided into 4 stages: fan delta-lake-volcanic rock filling period; fault depression basin in braided river sedimentary period; depression basin in meandering river sedimentary filling period and depression lake basin sedimentary period flood plain. During sedimentary filling stage of meandering river deposition in depression basin, after Deng-2 section had been deposited, this basin evolved to water-storage depression basin, then Deng-3 section began depositing. In this stage, water body area expanded and submerged salient, and deposition began in whole region, material source changed to northern provenance from middle provenance, the deposition changed to meandering river from braided river. Because of the damp climate, large rainfall, floods, the direction of river evolved to southeast from northeast and northwest. Sediments were supplied sufficiently [7], extensively developed river flooding formed. In this stage, sandstone mainly deposited, channel sand bodies developed very well, the maximum thickness of sandstone beds up to 160 meters, the minimum thickness is $50 \mathrm{~m}$.

\section{Reservoir Prediction}

To find out the characteristics of reservoir thickness distribution of Deng-3 section formation, based on drilling data, combined with seismic attributes and the plane distribution of the ratio of sandstone to formation, the reservoir thickness of each layer was predicted.

Strata thickness of the lower part of Deng-3 section. The reservoir of the lower part of Deng-3 section (D3x) is developed very well, the reservoir thickness is from $5 \mathrm{~m}$ to $85 \mathrm{~m}$, it is over $25 \mathrm{~m}$ in most areas, the high value area of reservoir thickness distributes nearly a north-south direction strip, and can be divided into three zones: in Daqing step-fault zone at the west side of this strip, formation thickness is larger, the sandstone thickness of reservoir is between $35 \mathrm{~m}$ to $85 \mathrm{~m}$ in the northern of this zone, and between $25 \mathrm{~m}$ to $60 \mathrm{~m}$ in the southern of this zone, the sandstone thickness overall is larger, generally in $50 \mathrm{~m} \sim 60 \mathrm{~m}$. In Xuxi slope break belt at the east side of this strip [8], sandstone thickness is relatively larger, at $25 \mathrm{~m} \sim 60 \mathrm{~m}$, generally at around $40 \mathrm{~m}$. The smaller sandstone thickness is in the central uplift belt, sandstone thickness overall is relatively smaller, usually between $25 \mathrm{~m}$ and $60 \mathrm{~m}$, the larger thickness sandstone is located near the Well Fangshen-6 and Well Fangshen-4 stratum is missed near Well Da-2 in northern and Yongle area in southern of this uplift belt.. 
Strata thickness of the upper part of Deng-3 section. Compared with the lower part (D3x) strata of Deng-3 section, the upper strata (D3s) inherits the distribution features of the lower part of the Deng-3 section, sandstone reservoir is more developed, the sandstone thickness of the strata is from $20 \mathrm{~m}$ to $85 \mathrm{~m}$, thickness is more than $35 \mathrm{~m}$ in most areas, the high value area of reservoir thickness distributes nearly a north-south direction strip too [9], and can obviously be divided into three zones: in Daqing step-fault zone at the west side of this strip, formation thickness is larger, the sandstone thickness of reservoir is between $35 \mathrm{~m}$ to $85 \mathrm{~m}$ in the northern of this zone, and between $25 \mathrm{~m}$ to $55 \mathrm{~m}$ in the southern of this zone, the sandstone thickness overall is larger, generally in $50 \mathrm{~m} \sim 60 \mathrm{~m}$. In Xuxi slope break belt at the east side of this strip, sandstone thickness is larger too, at $25 \mathrm{~m} \sim 60 \mathrm{~m}$, generally at around $40 \mathrm{~m}$. The smaller sandstone thickness is in the central uplift belt, usually between $25 \mathrm{~m}$ and $50 \mathrm{~m}$, the larger thickness sandstone is located near the Well Fangshen-6 and Well Fangshen-4 stratum is missed near Well Da-2 in northern and Yongle area in southern of this uplift belt. the larger thickness sandstone is located in the southwest corner of Well Zhaoshen-3 in southern area, and the thickness is up to $60 \mathrm{~m}$.

\section{Summary}

(1) The sand group sedimentary microfacies is analyzed in 47 wells of the whole region in detail. Deng-3 section mainly developed fluvial facies. on this basis, the spatial distribution pattern of sedimentary microfacies in each interval was studied though compiling a joint-well sandstone analysis profile map with the selected 10 controlled frame profile.

(2) On the basis of analysis of single well sedimentary microfacies, associated well sand body connectivity and seismic facies, in combination with regional sedimentary background, geomorphology, thickness and lithology, the sedimentary system was analyzed.

(3)To find out the reservoir thickness distribution of Denglouku formation, based on drilling data, combined with seismic attributes and the plane distribution of sandstone-formation ratio, the reservoir thickness of each layer was predicted.

\section{References}

[1]Junliang Chen, Xiyuan Cai, Chunhua Lin, etc. In the north of songliao basin downfaulted basin tectonic characteristics and episodic evolution, Journal of oil, 20 (1999) 14 - 20.

[2]Chunmei Dong, Xianguo Zhang, Chengyan Lin. Seismic sedimentology of concepts, methods and techniques, Journal of sedimentary. 24 (2006) 698-704.

[3]Zongbao Liu. High resolution sequence stratigraphy and hydrocarbon accumulation model of Fuyu reservoir in Sanzhao Depression, Master's thesis of Northeast Petroleum University. 2010. ( In Chinese)

[4]Guizhou Jiang. Cenozoic basin formation and evolution in the northeast China, Journal of daqing petroleum institute. 21 (1997) 1-6. ( In Chinese)

[5]YiNan Qiu, Zhisong Zhang, Meifang Tang, etc. A small river sand body reservoir layer contrast, Petroleum exploration and development. 2(1987)46-52. ( In Chinese)

[6]Sitian Li. Including energy basin sedimentary system, Master's thesis of China university of geosciences press. 1996. ( In Chinese)

[7]Sitian Li, Xinong Xie, Hua Wang, etc. Sedimentary basin analysis and application[M], Higher education press. 2004. ( In Chinese)

[8]Yan Su, Yu Yang, Zhenhua Bai, et al. A study of depositional microfacies and method of reservoir prediction by integrating well log and seismic information in dense well pattern-taking Xing 56 block, Xingshugang oil field, Daqing as an example. Earth Science Frontiers(China University of Geosciences, Peking University), 15(2008)110-116. ( In Chinese) 
International Forum on Energy, Environment Science and Materials (IFEESM 2015)

[9]Shirui Wang, Shuping Wang, bangrang Di,et al. Prediction of channel sand body based on seismic attributes, Oil Geophysical Prospecting. 44(2009)304-313. 